Web Jurnal Online: jurnal.unmuhjember.ac.id By: Ach. Apriyanto Romadhan, Laeli Nur Khanifah, Iradhad Taqwa Sihidi

Muhammad Kamil

The Role Of Bossism In Practice Of Gambling Election Of Village Head In Batu City

\title{
THE ROLE OF BOSSISM IN PRACTICE OF GAMBLING ELECTION OF VILLAGE HEAD IN BATU CITY
}

\author{
Ach. Apriyanto Romadhan \\ Laeli Nur Khanifah \\ Iradhad Taqwa Sihidi \\ Muhammad Kamil \\ University of Muhammadiyah Malang \\ achapriyantoromadhan@umm.ac.id \\ khanifah92@umm.ac.id \\ iradhad@umm.ac.id \\ kamil@umm.ac.id
}

\begin{abstract}
The practice of gambling in holding village head elections was allegedly threatening democratization at the local level. Instead of being an example of the uniqueness of local democracy in Indonesia, village head election democracy is colored by the practice of money politics. In every village head election, including in Batu city, it is always colored by the presence of Botoh or gamblers. In some studies, Botoh is interpreted as a broker or broker in financing the political costs of a village head candidate. Their position is in outside the structure of government. Their presence in the practice of village head election gambling is suspected because of economic motives. This research offers different things. Understanding botoh is not only those who are outside the government structure, but they are also people who are inside the government structure. Based on these conditions, this study wants to answer how the dynamics of botoh in the practice of village head election gambling at the local level. The research in this paper uses a type of qualitative research with a descriptive approach. In collecting data researchers used interview techniques with an open model, participatory observation and documentation. Data analysis using an interactive analysis model, this study tries to display descriptive data. The technique of taking informants is done by purposive sampling and snowball The involvement of botoh or gamblers in each organization of village head elections is due to their perception of the meaning of village head elections as a gambling arena. Their orientation in the administration of pilkades as a venue for capital accumulation. Unlike the botoh motives, some botohs are in the government structure, they are politicians who have the interest to finance the winning of village head candidates, with the hope that besides economic motives, the victory of village head candidates who are supported guarantees the continuity of their power structure. In an open electoral system, the village head can be used as a voice broker to ensure voter voting mobility to the politician.
\end{abstract}

Keywords: Gambling, Village Head Election, Botoh 
Proceeding ICOGISS 2019

Page 899-909. ISBN: 978-602-6 988-75-1

Web Jurnal Online: jurnal.unmuhjember.ac.id By: Ach. Apriyanto Romadhan, Laeli Nur Khanifah, Iradhad Taqwa Sihidi Muhammad Kamil

The Role Of Bossism In Practice Of Gambling Election Of Village Head In Batu City

\section{Introduction}

It needs a rereading in interpreting the Election of Village Heads (Pilkades) as a form of democracy ${ }^{1}$. There are at least several reasons to support this statement, firstly the Pilkades are not merely meant as a struggle for power in the context of leadership succession, but also concerning self-esteem and honor ${ }^{2}$. The implication is that various campaign strategies are carried out, not only through legal means but also by illegal means, one way to achieve power is through the practice of money politics. This practice can at least be traced in several studies, for example, the findings of Kartodirdjo $(1992)^{3}$ and Kana $(2001)^{4}$ _which states in the context of the Pilkades, money politics is used as a tactic to win candidates.

The second assumption is to redefine the democratic process in the election of village heads by looking at how democratic participation ${ }^{5}$ is the public in channeling their political choices. Compared to that expectation, the Pilkades reduced the space for community participation to channel their political rights to elect a village head

\footnotetext{
${ }^{1}$ Opinions that hold this view suggest that village democracy as a form of genuine democracy that is different from western democracies that have characteristics such as deliberation, village consultation and the election of village heads by the people in the village, from the candidates they propose themselves. For further details please see: Ina E. Sla met. 1965. Principles of Village Community Development. Djakarta : Bharata and HAW Widjaja. 2008. Village Autonomy is genuine, round and whole. PT.Raja Grafindo Persada: Jakarta.

${ }^{2}$ For example in Madura, the election of village heads by contesting elites is not only interpreted as a circulation of power but is also interpreted as self-esteem and family honor, see: Ainilah, SR (2016). Political Elite in Village Contents Using Study of the Role of Blater in Pilkades in Banjar Village, Galis, Bangkalan Madura. Journal of Youth Politics. [ Internet] [downloaded 2018 December 4] , 5 (3), 282-290, see also Cahyono, H. (2005). Political Elite Conflict in the Rural: Relations between the Village Representative Body and the Village Government. Journal of Political Research, 2 (1), 73-84.

${ }^{3}$ Kartodirdjo, Sartono (1992). Feast of Democracy in the Rural: Case Study of Pilkades in Central Java and DIY. Yogyakarta: Aditya Media.

${ }^{4}$ Kana, Nico L (2001). "Management Strategy of Village Elite Political Competition in the District of Suruh: The Case of Election of Village Heads", Renai Journal Year 1, No.2, April-May 2001, p. 5-25

${ }^{5}$ Huntington sees participation in society in the context of democracy as awareness, and volunteerism with notes of participation being mobilized is also included in the study of political participation, see Samuel P. Huntington and Joan Nelson. 1994. Political Participation in Developing Countries. PT Rineka Cipta: Jakarta, pp. 9-14
} 
Proceeding ICOGISS 2019

Page 899-909. ISBN: 978-602-6 988-75-1

Web Jurnal Online: jurnal.unmuhjember.ac.id By: Ach. Apriyanto Romadhan, Laeli Nur Khanifah, Iradhad Taqwa Sihidi Muhammad Kamil

The Role Of Bossism In Practice Of Gambling Election Of Village Head In Batu City

democratically, Ratnasari $(2016)^{6}$ actually see that increasing public participation has a positive correlation with increasing practices of money politics in village head

elections finally, the election of village heads is no longer an arena of democracy for the people, but a gambling arena. This gambling practice colors various organizing village head elections in various regions in Indonesia, for example in Karawang ${ }^{7}$, in Pamekasan $^{8}$, in Malang _and Batu ${ }^{10}$. This condition shows that gambling at the time of village head election is used as an arena for gambling practice. Even in the case of the District Police, it is very common for people to find gambling practices. Perpetrators commonly referred to as petaro / pemaen (gamblers) in Madura Language, and Javanese language is known as botoh. Fauzi ${ }^{11}{ }_{-}$even mentioned that the botoh embryo originated from village head election gambling.

Even the actors involved in this gambling activity are various, not only followed by the botoh. Halili (2009) $)^{12}$ and Amanu $(2015)^{13}$, seeing that the practice of money/gambling politics in village head elections involves three actors namely the village head, the success team, and the gambler. The involvement of the three actors in the practice of village head election gambling is at least based on various motives. Fauzi for example (2017) ${ }^{14}{ }_{-}$stated that botoh and prospective executives practiced gambling in the village chief contestation at least based on fighting over capital accumulation in gambling as well as fighting for power.

${ }^{6}$ Ratnasari, D. (2016). The Relationship between Acceptance of Money Politics and the Level of Political Participation in the Election of Village Heads in Munung Village, Jatikalen District, Nganjuk Regency. Moral and Citizenship Study, 4 (3).

${ }^{7}$ https://www.liputan6.com/regional/read/3660921/hand-cold-bandar-judi-t specifywinners- pilkades- di- karawang

${ }^{8}$ http://radarmadura.jawapos.com/read/2017/10/03/17130/judi-pilkades-jadi-atensipolres-pamekasan

${ }^{9}$ https://radarmalang.id/dari-judi-pilkades- border- 29-muka- baru/

${ }^{10} \mathrm{https} / / /$ radarmalang.id/polres-endus-praktik-judi-pilkades/

${ }^{11}$ Fauzi, AM (2017). Gambling Hegemony in Local Elections in Indonesia. DIMENSION-Journal of Sociology, 10 (2).

${ }^{12}$ Halili, O. Money Political Practices In Selecting The Village Head. Journal of Humanities Research , 14 (2).

${ }^{13}$ Amanu, M. (2015). Money Politics in the Election of Village Heads (Case Study in Jatirejo Village, B Tanya District, Kediri Regency). Journal of Student Sociology, 1 (2).

14 Fauzi, AM (2017). Gambling Hegemony in Local Elections in Indonesia. DIMENSION-Journal of Sociology, 10 (2). 
Proceeding ICOGISS 2019

Page 899-909. ISBN: 978-602-6 988-75-1

Web Jurnal Online: jurnal.unmuhjember.ac.id By: Ach. Apriyanto Romadhan, Laeli Nur Khanifah, Iradhad Taqwa Sihidi Muhammad Kamil

The Role Of Bossism In Practice Of Gambling Election Of Village Head In Batu City

Some of the research above explains that Botoh is an informal actor outside the government structure. The relationship between the two is just a transactional relationship that is symbiotic in mutualism. Botoh bet with the village head and include capital to win the village head for the cost of political money in the hope of getting economic benefits from gambling, while the village head hopes to gain power from botoh support through gambling practices and vote-buying.

Looking at the relationship between botoh and village heads in the practice of village head election gambling in this study is interpreted differently. Botoh in the practice of village head election gambling is interpreted as bossism. By Sidel, the local boss / bossism is a formal state actor who joins and forms a network that is rooted to the lowest regional level and tries to monopolize his power at the local level ${ }^{15}$.

In this research, gambling activities involve state formal actors who join and form networks that are rooted in the lowest regional level (village) and try to monopolize their power at the local level. Practice gambling in village elections feels is not only done by an informal actor but also carried out by supra-level formal actor 's structures are at the village. Gambling activities in the election of village heads in Batu City are marked as being carried out by legislative members ${ }^{16}$. By Sidel activities carried out by bossisme (formal actor) is done to retain power by way of leaning power superordinate or symbiosis mutualism to be political brokers including through votebuying and fraud in elections by hanging $d$ jealous of institutions and state power. The above explanation leads this research to find the answer to the question: "what is the role of bossism in the practice of village head election gambling in Batu city?"

\section{Literature Review}

\subsection{Local Strong People and Bossism}

${ }^{15}$ Sidel, John T. Bosisme and Democracy in the Philippines, Thailand and Indonesia, Towards a New Analysis Framework About "Local Strong Man" dalam John Harris, Kristian Stoke and Olle Tornquist. . the original title Politicising Democracy: The New Local Politics of Democratizaton, translated into Indonesian by Arya Wisesa, Bernadetta Esti Sumarah, Lina Jusuf. 2005. Politicization of Democracy: New Local Politics. Jakarta: DEMOS, p. 86

${ }^{16}$ Results of interviews with informants, 20 February 2019 
Proceeding ICOGISS 2019

Page 899-909. ISBN: 978-602-6 988-75-1

Web Jurnal Online: jurnal.unmuhjember.ac.id By: Ach. Apriyanto Romadhan, Laeli Nur Khanifah, Iradhad Taqwa Sihidi Muhammad Kamil

The Role Of Bossism In Practice Of Gambling Election Of Village Head In Batu City

Initial references from the study of local strongmen can be traced to the text of Migdal. Migdal defines "local strongmen" as informal leaders outside the country such as landlords, bosses, and moneylenders who build their social organizations in the form of networks to exercise social control over the community to control the entire population inhabiting certain areas. In the history of local politics in Indonesia, the presence of local strongmen can be traced through a variety of socio-historical conditions and the culture of the local community. Each region has various terms to describe what is meant by local strongmen. In Banten, for example, local strongmen were described by the nickname Jawara, in Madura local strongmen were known as bhejingan ${ }^{17}$, while in Java it is known by the name Botoh .

According to Migdal local strongmen operate in third world countries which are still weak. They carry out various activities such as providing security and extortion, applying gifts, punishments, and symbols as a form of social control over society. Local strongmen exercise social control over their people, especially at the local level, the implication is that they succeed in blocking and limiting the capacity of institutions and state apparatus so that the state is weak.

Social control is mainly carried out to regulate social relations within the community, penetrate within the community, extract resources available within the state and use resources available within the state ${ }^{18}$.

In contrast to Migdal which states that local strongmen are informant actors who are outside the state, John Sidel modified Joel Migdal's theory of "local strongmen". According to him "local strongman" is "local bossism". Local bossism in Sidel's research in the Philippines, Thailand, and Indonesia took the form of mayors, members of Congress and governors who became brokers of power for their political patrons at the national level. These "local bossism" arises through competent and periodic electoral mechanisms and is followed by high political participation. They use a variety of

\footnotetext{
${ }^{17}$ Ach. Apriyanto Romadhan. 2018. The Role Of Bhejingan in The Selection of Village Chief. Journal of Local Government Issues, Vol 1 No 2, pp. 244-269

${ }^{18} \mathrm{M}$ i g d al, J o el S . 2004. State in Society: Studying How States and Societies

Transform and Constitute One Another. Cambridge: Cambridge

Uni ver s i t y P re ss, h al 88- 94
} 
Proceeding ICOGISS 2019

Page 899-909. ISBN: 978-602-6 988-75-1

Web Jurnal Online: jurnal.unmuhjember.ac.id By: Ach. Apriyanto Romadhan, Laeli Nur Khanifah, Iradhad Taqwa Sihidi Muhammad Kamil

The Role Of Bossism In Practice Of Gambling Election Of Village Head In Batu City

strategies from buying voters' votes, manipulating voters to intimidation by using violence ${ }^{19}$.

They gain monopoly control over society through the mastery of coercive power and economic resources in their respective territorial power jurisdictions such as control of infrastructure contracts, mining or logging contracts, transportation companies, illegal economic activities including the ability to mobilize voters, and vote purchase. To maintain power and control over economic resources they rely on superordinate power by becoming a political broker of power over it through the use of violence, vote-buying, and fraud in elections by relying on state institutions and power.

Finally, in the context of development, the presence of local strongmen no longer hinders and limits the capacity of the state as Migdal said, but local bosses with globalization and international capital flows can adapt and become servants of economic growth. Development projects in third world countries are seen as opportunities to enrich themselves and maintain their networks by controlling all forms of economic resources that are widely disbursed by the state.

\subsection{Village Head Election Gambling}

Gambling or gambling in a big dictionary language Indonesia interpreted as a game by using money as a bet ${ }^{20}$. Gamblers or people who gamble risk a certain amount of money or assets to obtain financial or material benefits greater than the capital at stake. This definition means that gambling activities are only intended to get capital accumulation.

The different definition was given by Kartini, he explained that what was meant by gambling was an activity that was deliberately carried out by risking one value or something that was considered valuable by recognizing the existence of certain risks and

${ }^{19}$ Sidel, John T. Bosisme and Democracy in the Philippines, Thailand and Indonesia, Towards a New Analysis Framework About "Local Strong Man" dalam John Harris, Kristian Stoke and Olle Tornquist. . the original title Politicising Democracy: The New Local Politics of Democratizaton, translated into Indonesian by Arya Wisesa, Bernadetta Esti Sumarah, Lina Jusuf. 2005. Politicization of Democracy: New Local Politics. Jakarta: DEMOS, p. 75-98

20 Poerwadarminta,. 1995. Large Indonesian Dictionary, Second Edition. Balai Pustaka,: Jakarta . p 419. 
Proceeding ICOGISS 2019

Page 899-909. ISBN: 978-602-6 988-75-1

Web Jurnal Online: jurnal.unmuhjember.ac.id By: Ach. Apriyanto Romadhan, Laeli Nur Khanifah, Iradhad Taqwa Sihidi Muhammad Kamil

The Role Of Bossism In Practice Of Gambling Election Of Village Head In Batu City

expectations on events, games, competitions, and events. events that are not / are not yet certain results ${ }^{21}$. The definition has a pressure point that gambling activities are not just oriented towards material values but also the material values of gamblers.

In the Republic of Indonesia Government Regulation Number 9 of 1981 concerning the Implementation of Law Number 7 of 1974 concerning the Controlling of Gambling Article 1 Paragraph (1) whose formulation "granting licenses to administer all forms and types of gambling is prohibited, both gamblings held in casinos, in places crowded places, as well as those related to other reasons. "This means that all gambling including gambling to elect the Village Head is a criminal offense that can be prosecuted legally.

Gambling in the village head election is not only meant as a betting activity to obtain financial and material benefits from just guessing potential winners or guessing votes. Gambling in the village head election is interpreted as an activity to gain material (economic) benefits and material benefits (power, prestige, and honor) by making various efforts to influence voters and the election cycle.

\section{Results and Discussion}

\subsection{Understanding the Bossism of Santrean Hamlet, Sumberejo Village, Batu City}

BDRT (55) is a child born to a respected family in his village. His father was a master land in the hamlet Santrean leading Sumberejo village. Stepping on adolescence after graduating from high school (high school) BDRT continued their education at one of the universities in Jakarta. In contrast to teenagers of his age who cannot get higher education like himself, BDRT is increasingly respected by residents. After graduating, BDRT married a woman from Donomulyo Village, Malang Regency. His wife is one of the rich people in Donomulyo Village.

Since the 1980s, BDRT has been one of the dominant party politicians in Indonesia. In the medium of 1988, the BDRT ran for the village head election in Sumberejo. BDRT along with one other candidate participated in the democratic party at the local level. Armed with capital, Jakarta graduate and practice of money politics BDRT out as a winner in the contestation of the village head election ( period 1988-1996

${ }^{21}$ Kartini Kartono. 2005. Social Pathology, volume I. PT Raja Grafindo Persada: Jakarta. Page 56 
Proceeding ICOGISS 2019

Page 899-909. ISBN: 978-602-6 988-75-1

Web Jurnal Online: jurnal.unmuhjember.ac.id

By: Ach. Apriyanto Romadhan, Laeli Nur Khanifah, Iradhad Taqwa Sihidi

Muhammad Kamil

The Role Of Bossism In Practice Of Gambling

Election Of Village Head In Batu City

and the period 2017-2013). To build relations with the voters (community) BDRT is always present at every event carried out by the community, not only that he also gives a contribution that is not small in number.

During his tenure as head of the BDRT village, he was also a client of the party supporting him. During his tenure as head of the BDRT village, he must ensure that the people he leads do not provide support or affiliation with parties outside the party he supports. When serving as village head BDRT discriminated against services. BDRT does not provide service maintenance of letter correspondence administration of population due to the people who need the services of differing views politician yes or different with the party. It is not only done to the public, but also to his family own the opposite party $\mathrm{d}$ it supports.

In addition to serving as village head and party politician, BDRT built its power by creating a limited liability company (PT) engaged in property and land buying and selling. During the leadership as the head of the village, BDRT tangled case of the sale of the village on behalf of PT which is owned to the developer who will build housing, this case Menda $\mathrm{p}$ at special attention from the public so that the housing construction stalled.

After no longer arguing as village head in 2013, BDRT developed his political career with his wife to run for legislative candidates in the 2014 general election through the Gerindra Party where the wife nominated in Batu 1 constituency which included Pesanggrahan Village, Ngaglik Village, Songgokerto Village, Sumberejo Village and Sidomulyo Village while BDRT itself nominated in electoral area 3 namely Bumiaji District, and the result was that Budiarto and his wife won the election.

\subsection{The Role of Bosism in Pilkades in Batu City}

Besides being a BDRT Politician and Entrepreneur, he is also well-known as a big gambler who is quite well known. Gambling activities carried out by BDRT are mainly carried out in every village head election. Based on one of the residents told that BDRT brought back two sacks of rice from the gambling practices of the village head in Giripurno Village, Batu District, Batu City.

The practice of gambling in the village head election was carried out by surveying a botoh team. The team is tasked with calculating the real number of voters and their political choice tendencies, in this way the possibility of the accuracy of sound 
Proceeding ICOGISS 2019

Page 899-909. ISBN: 978-602-6 988-75-1

Web Jurnal Online: jurnal.unmuhjember.ac.id

By: Ach. Apriyanto Romadhan, Laeli Nur Khanifah, Iradhad Taqwa Sihidi

Muhammad Kamil

The Role Of Bossism In Practice Of Gambling

Election Of Village Head In Batu City

mapping is higher because it does not only use sampling. This survey is conducted to see candidates who have the strongest potential win or to candidates who narrowly lost the survey results but can be jacked up by the practice of political money. One of the factors BDRT wins in every gambling is the strategy of sharing money or political money, where BDRT attracts relatives and networks to campaign in each environment and give money for fifty thousand rupiahs for each person.

This mapping needs to be done to ensure victory when gambling later. The gambling practices carried out by BDRT not only do gambling horizontally with fellow gamblers, especially gamblers outside the village who hold village head elections but also do vertical gambling with participants or contestants in village head elections. This is done in addition to increasing the economic benefits he gets in the practice of gambling village head elections but also the political capital he gained when running for legislative membership.

Therefore BDRT also in addition to acting like a gambler, is also raised funds in village elections so that the contestant who he supported having additional capital to make the practice of money politics. BDRT through its network of gambling friends also builds false information that is spread through stalls and community gathering places that the Candidate for the Village Head that he supports loses in the betting market. This is done so that other gamblers feel the upper hand when going to make a bet with him. In conducting its gambling actions BDRT moves not alone. BDRT along with its trust team secretly spread the citizens' envelopes to choose the candidate he supports to win the bet.

\section{Conclusion}

The role of Botoh in the election of village heads is not only orientation to materialistic interests, such as the accumulation of capital that can be obtained when winning gambling. Also, there is also a long-term pragmatic motivation, namely the importance of the smooth distribution of political resources. Through the gambling election practice by mapping voters and involving capital for prospective village heads, BDRT can build a patronage network as political capital to advance in legislative elections at the regional level. 
Proceeding ICOGISS 2019

Page 899-909. ISBN: 978-602-6 988-75-1

Web Jurnal Online: jurnal.unmuhjember.ac.id By: Ach. Apriyanto Romadhan, Laeli Nur Khanifah, Iradhad Taqwa Sihidi Muhammad Kamil

The Role Of Bossism In Practice Of Gambling Election Of Village Head In Batu City

\section{References}

Ainilah, SR (2016). Political Elite in Village Contents Using Study of the Role of Blater in Pilkades in Banjar Village, Galis, Bangkalan Madura. Journal of Youth Politics. [ Internet] [downloaded in 2018 December 4] , 5 (3).

Amanu, M. (2015). Money Politics in the Election of Village Heads (Case Study in Jatirejo Village, B Tanya District, Kediri Regency). Journal of Student Sociology, 1 (2).

Cahyono, H. (2005). Political Elite Conflict in the Rural: Relations between the Village Representative Body and the Village Government. Journal of Political Research, 2 (1)

Fauzi, AM (2017). Gambling Hegemony in Local Elections in Indonesia. DIMENSIONJournal of Sociology, 10 (2).

Halili, O. The Practice of Money Politics in the Election of Village Heads. Journal of Humanities Research, 14 (2).

HAW Widjaja. 2008. Village Autonomy is genuine, round and whole. PT.Raja Grafindo Persada: Jakarta.

Huntington, Samuel P., and Joan Nelson. 1994. Political Participation in Developing Countries. PT Rineka Cipta: Jakarta

Ina E. Sla met. 1965. Principles of Village Community Development. Djakarta : Bharata

Kana, Nico L (2001). "Management Strategy of Village Elite Political Competition in the District of Suruh: The Case of Election of Village Heads", Renai Journal Year 1, No.2, April-May 2001, p. 5-25

Kartini Kartono. 2005. Social Pathology, volume I. PT Raja Grafindo Persada: Jakarta. Page 56 Kartodirdjo, Sartono (1992). Feast of Democracy in the Rural: Case Study of Pilkades in Central Java and DIY. Yogyakarta: Aditya Media

$\mathrm{J}$ o h n Ha rr i ss, $\mathrm{K}$ ri s ti a $\mathrm{n} \mathrm{St} \mathrm{ok} \mathrm{ke} \mathrm{a} \mathrm{nd} \mathrm{Olle} \mathrm{T}$ or $\mathrm{nqu}$ i s t. the original title Po litici s in g Dem o c r a cy: The N ew Lo c a l Po Litic s of Dem o c r a tiz a to $n$, translated into Indonesian by Arya Wisesa, Bernadetta Esti Sumarah, Lina Jusuf. 2005. Politicization of Democracy: New Local Politics . Jakarta: DEMOS

M i g d al, J o el S . 2004. State in Society : STUDYING HOW STATES AND SOCIETIES TRANSFORM AND CONSTITUTE ONE ANOTHER . Cambridge : Camnbridge U n i v e r s i t y P r e ss.

Miles, MB and MA Huberman. 1992. Qualitative Data Analysis . University of Indonesia Publisher: Jakarta 
Proceeding ICOGISS 2019

Page 899-909. ISBN: 978-602-6 988-75-1

Web Jurnal Online: jurnal.unmuhjember.ac.id By: Ach. Apriyanto Romadhan, Laeli Nur Khanifah, Iradhad Taqwa Sihidi

Muhammad Kamil

The Role Of Bossism In Practice Of Gambling

Election Of Village Head In Batu City

Moleong, Lexy J. (2014). Qualitative Research Methodology, Revised Edition. Bandung: PT Remaja Rosdakarya

Poerwadarminta „. 1995. Large Indonesian Dictionary, Second Edition. Balai Pustaka,: Jakarta .

Ratnasari, D. (2016). The Relationship between Acceptance of Money Politics and the Level of Political Participation in the Election of Village Heads in Munung Village, Jatikalen District, Nganjuk Regency. Moral and Citizenship Study, 4 (3)

Romadhan, Ach. 2018. 2018. The Role Of Bhejingan in The Selection of Village Chief. Journal of Local Government Issues, Vol 1 No 2, pp. 244-269.

http://ejournal.umm.ac.id/index.php/LOGOS/article/view/5814

https://www.liputan6.com/regional/read/3660921/hand-cold-bandar-judi-t $\quad$ specifywinners-pilkades-di-karawang

http://radarmadura.jawapos.com/read/2017/10/03/17130/judi-pilkades-jadi-atensi-polrespamekasan

https://radarmalang.id/dari-judi-pilkades-atin-29-muka-baru/

https://radarmalang.id/polres-endus-praktik-judi-pilkades/ 